\title{
ANALISIS PEMHAMAN MASYARAKAT KOTA PALEMBANG TENTANG WAKAF PRODUKTIF DAN UANG
}

\author{
Listiawati (listiawati_uin@ @radenfatah.ac.id) \\ UIN Raden Fatah Palembang
}

\begin{abstract}
Abstrak
Penelitian dengan judul Analisis Pemahaman Masyarakat Kota Palembang Terhadap Wakaf Produktif dan Uang.Wakafdi Indonesia adalah merupakan salah satu lembaga Islam yang sangat erat kaitannya dengan masalah sosial dan adat.Dalam masyarakat wakaf sering dianggap sebagai masalah adat dan juga terkadang dianggap sebagai masalah hukum Islam. Mengingat memang mayoritas penduduk Indonesia adalah muslim di samping itu juga tradisi wakaf atau lembaga perwakafan itu yang memang lembaga yang berasal dari ajaran agama Islam, tetapi juga seolah-olah sudah merupakan kesepakatan di antara para ahli hukum bahwa lembaga perwakafan tersebut adalah merupakan masalah hukum adat di Indonesia. Dan sempitnya pola pemahaman masyakat terhadap harta yang akan diwakafkan yaitu berupa harta benda yang tidak bergerak saja seperti tanah untuk mushalla, madrasah dan lainnya. Sampai saat ini masih minimnya harta wakaf yang dikelola secara produktif. Penelitian ini akan merumuskan bagaimana pemahaman masyarakat kota Palembang terhadap wakaf produktif dan uang. Dengan tujuan ingin menganalisis sejauhmana pemahaman masyarakat kota Palembang terhadap wakaf produkif dan uang. Metode penelitian, penelitian ini adalah penelitian lapangan (fild research) dengan jenis penelitian adalah penelitian kuantitatif yakni dengan mengolah dan menganalisis data-data yang diperoleh dari lapangan, juga aturan-aturan pemerintah. Hasil dari penelitian ini bahwa sampai saat ini, masih minimnya pemahaman masyarakat kota Palembang terhadap wakaf produktif dan uang, sehingga masih sedikit harta wakaf yang dikelola secara produktif yang bisa dirasakan bentuk manfaatnya oleh masyarakat banyak. Sebagai contoh harta wakaf yang dikelola dan dikembangkan dengan baik adalah: Yayasan Pemeliharaan dan Perluasan Wakaf Pondok Moderen Gontor Jawa Timur, Yayasan Badan Wakaf Sultan Agung, Badan Wakaf Universitas Islam Indonesia (UII) Yogyakarta, Badan Wakaf Universitas Muslimin Indonesia (UMI) Makasar, Yayasan Wakaf Paramadina dan lain-lain. Munculnya bank-bank syari'ah, khususnya yang dimotori oleh bank-bank besar konvensional di hampir seluruh pelosok tanah air memberikan angin besar dan optimisme tinggi bagi umat Islam, termasuk di dalamnya pengelolaan harta (dana) wakaf secara produktif. Untuk harta wakaf yang berbentuk harta tidak bergerak seperti tanah dan bangunan, pihak bank syari'ah bisa menjadikannya sebagai agunan (jaminan) peminjaman sejumlah dana dalam rangka pengembangan harta wakaf yang lain. Sedangkan kalau dalam bentuk tunai (cashwakaf), maka pihak bank bisa langsung mengelola, mengembangkan dan menyalurkan harta wakaf yang dipercayakan kepada bank tersebut.
\end{abstract}

Kata Kunci: Pemahaman Masyarakat Wakaf Produktif dan Uang 
I-Finance Vol. 4. No. 1. Juni 2018

Analisis Pemahaman Masyarakat Kota Listiawati

\section{PENDAHUUAN}

Karakteristik ekonomi Islam tercakup bahasan tentang sektor moneter (keuangan Islam) dan bahasan lainnya sektor riil (produksi, konsumsi dan distribusi). Dalam hal distribusi untuk menciptakan keadilan dan kesejahteraan rakyat, maka Islam mengajarkan bahwa bagi umat Islam diwajibkan untuk mengeluarkan zakat baik zakat fitrah maupun zakat mal namun dalam hal ibadah sunnah Islam juga mengajarkan untuk bersedekah, infak, kurban, mewakafkan hartanya bagi yang berlebih. Di Indonesia wakaf adalah merupakansalah satu lembaga Islam yang sangat erat kairtannya dengan masalah sosial dan adat.Dalam masyarakat wakaf sering dianggap sebagai masalah adat dan juga terkadang dianggap sebagai masalah hukum Islam.Mengingat memang mayoritas penduduk Indonesia adalah muslim di samping itu juga tradisi wakaf atau lembaga yang serupa memang telah lama ada walaupun dalam pelaksanaannya masih belum teratur, maka pihak penguasa, baik pemerintah Hindia Belanda maupun pemerintah Indonesia merasa berkepentingan untuk merespon kepentingan ini. Dengan demikian, terlepas dari motif dan tujuannya, keberadaan wakaf secara legalitas formal sebagai implementasi dari 'political will' penguasa, yang nampaknya memang telah muncul pada masa pemerintahan Hindia Belanda disusul setelah kemerdekaan Republik Indonesia. Tahap demi tahap keinginan baik penguasa atau pemerintah untuk menumbuh kembangkan lembaga wakaf semakin terlihat (Duski Ibrahim, 2008:15).

Di Indonesia sampai saat ini telah diatur dengan berbagai aturan perundang-undangan yang menyangkut wakaf yakni dengan adanya UU No 5 tahun 1960 yang berisi tentang Undang-undang Pokok Agraria (UUPA), Peraturan Pemerintah No 28 Tahun 1977, tentang Perwakafan Tanah Milik Jumto PMDM No 6 Tahun 1977 dan PMA No. 1 Tahun 1978, Instruksi Presiden No 1. Tahun 1991, tentang Kompilasi Hukum Islam (KHI) dan UU No. 16 Tahun 2001 tentang Yayasan. Adapun aturan yang terkait dentgan pengelolaan harta wakaf diatur oleh SK Dir. BI No. 32/KEP/DIR tentang Bank Umum Berdasarkan Prinsip Syariah dan SK Dir. BI No 32/36/KEP/DIR tentang Bank Perkriditan Rakyat Berdasarkan Prinsip Syari'ah. Dengan demikian jelas bahwa dalam hukum wakaf di Indonesia telah banyak diatur baik itu dalan perundang-undangan maupun peraturan yang lainnya yang berkenaan dengan masalah wakaf sekaligus cara pengelolaannya.

Pemerintah Indonesia akhirnya menetapkan Undang-Undang Nomor 41 Tahun 2004 tentang wakaf dan Peraturan Pemerintah Nomor 42 Tahun 2006 tentang Pelaksanan Undang-Undang Nomor 41 Tahun 2004. Peraturan perundang-undangan tersebut antara lain mengatur bentuk benda wakaf, yaitu benda tidak bergerak, dan benda bergerak dan uang (Suhrawardi, 2010:107). Dengan Undang-Undang Nomor 41 tahun 2004 Tentang Wakaf maka seharusnya memberi harapan bahwa pemberdayaan wakaf secara produktif melalui wakaf uang dapat berjalan dengan baik (Wadjdy, Farid dan Mursyid, 2007:26). Tentunya kesadaran dan pemahaman masyarakat akan betapa besar potensi wakaf produktif dan uang mempunyai peran penting dalam pengembangan pemberdayaan ekonomi masyarakat. 
Sumber daya manusia yang mengelola wakaf produktif dan uang harus mempunyai skill yang baik, amanah dan inovatif agar pengelolaan wakaf secara produktif dan wakaf uang dapat berkembang dengan baik. Sedemikian besarnya potensi yang dikandung, maka pengelolaan secara tekun, amanah, profesional dan penuh komitmen tentu akan mampu melepaskan ketergantungan Indonesia terhadap utang luar negeri yang telah menggunung hingga kini.

Dengan adanya political will dari penguasa atau pemerintah, melalui regulasi perwakafan, maka keberadaan wakaf semakin dipahami sebagai hal yang cukup pentinguntuk direspons oleh umat Islam Indonesia. Karenanya terlebih dahulu perlu dipahami secara baik landasan hukumnya, baik berdasarkan syariah maupun legalitas formal dari pemerintah.

\section{LANDASAN TEORI}

Dasar landasan perintah wakaf ini dapat dilihat dalam surah al-Hajj ayat 77 yang artinya: "Dan berbuatlah kebajikan, supaya kamu mendapat kemenangan (QS. al-Hajj ayat 77). Dalam surah Ali Imran ayat 92 yang artinya:“ Kamu sekalikali tidak sampai kepada kebajikan (yang sempurna) sebelum kamu menafkahkan sebagian hartayang kamu cintai (QS al-Imran ayat 92)." Dan surah al-Baqarah ayat 261. Tentang perumpamaan nafkah yang dikeluarkan oleh orang-orang yang menafkahkan hartanya di jalan Allah, adalah serupa dengan sebutir benih yang menumbuhkan tujuh butir, pada tiap-tiap butir menumbuhkan seratus biji, Allah melipatgandakan (ganjaran) bagi yang Ia kehendaki (QS al-Baqarah ayat 261).

Dalam hadits Rasulullah ia bersabda: Sesungguhnya Umar telah mendapatkan sebidang tanah di Khaibar. Umar bertanya kepada Rasulullah saw. “ Apakah perintahmu kepadaku yang berhubungan dengan tanah yang aku dapat ini? Jawab beliau jika engkau suka, tahanlah tanah itu dan engkau sedekahkan manfaatnya." Maka dengan petunjuk beliau itu lalu Umar sedekahkan manfaatnya dengan perjanjian tidak boleh dijual tanahnya, tidak boleh diwariskan (diberikan), dan tidak boleh dihibahkan.."(Hadits riwayat Bukhari Muslim).Menurut imam Syafii, inilah awal pertama kali wakaf yang masyhur di dalam Islam.

Dalam hadits lain yang diriwayatkan oleh Abu Hurairah, Sesungguhnya Rasulullah bersabda “ Apabila anak Adam (manusia) meninggal dunia, maka putuslah amalnya, kecuali tiga perkara: shadaqah jariyah, ilmu yang bermanfaat dan anak shaleh yang mendoakan orang tuanya (HR. Muslim).

Kelebihan amalan wakaf dibandingkan dengan amalan lainnya, hal ini dijelaskan dalam hadits riwayat Abu Hurairah, " Sesungguhnya Nabi saw. telah bersabda, 'Apabila seseorang meninggal dunia, terputuslah amalnya (tidak bertambah lagi kebaikan amalnya itu), kecuali tiga perkara: (1) sedekah (wakaf), (2) ilmu yang bermanfaat (baik dengan jalan mengajar maupun denga jalan karang-mengarang dan sebagainya), (3) anaka yang shaleh yangb mendoakan ibu bapaknya" (Hadits riwayat Jamaah).

Dari hadits di atas jelaslah bahwa berwakaf tidaklah sama halnya dengan bersedekah biasa, akan tetapi lebih besar ganjaran dan manfaatnya terhadap diri yang berwakaf itu sendiri, karena ganjaran wakaf it uterus menerus mengalir selama barang wakaf itu masih berguna. Juga terhadap masyarakat, dapat menjadi jalan kemajuan yang seluas-luasnya dan dapat menghambat arus kerusakan. 
Kata wakaf dapat diartikan dengan menahan suatu benda yang kekal zatnya, yang dapat diambil manfaatnya guna diberikan di jalan kebaikan. Difinisi wakaf menurut Abu Hanifah, yaitu: wakaf adalah menahan harta benda yang secara hukum tetap menjadin milik pewakaf (waqif) dan mensedekahkan manfaatnya untuk tujuan-tujuan kebaikan (Habs al-'ain 'ala hukm milknal-waqif wa at-tashadduq bi an-manf'ah 'alajihah al-khair (Ibnu Mansur Jamal al-Din Muhammad ibnu Mukarram al-Anshari, 2001:301). Dari definisi ini dapat dipahami beberapa hal sebagai berikut, yaitu, pertama, harta wakaf yang telah diwakafkan itu tidak hilang dari kepemilikan pewakaf (waqif) dengan kata lain bahwa harta itu tetaplah menjadi milik orang yang berwakaf. Kedua, yang disedekahkan atau didarmakan hanyalah manfaatnya saja, bukan pokok hartanya. Ketiga, wakaf itu sifatnya adalah ja'iz ghairu lazim, yakni hukumnya hanyalah boleh dan dianjurkan, akan tetapi tidaklah menghilangkan hak kepemilikan. Konsekuensinya, pewakaf dibolehkan untuk menarik kembali harta yang telah diwakafkannya tersebut sekaligus dapat menjualnya, dan manakala wakif meninggal dunia maka harta wakaf tersebut dapat menjadi harta warisan (Abu Bakar Muhammad bin Ahmad ibnu Abi Sarahsi al-Hanafi ).

Dalam menanggapi pendapat imam Abu Hanifah tersebut, maka imam Abu Yusuf mengatakan bahwa seandainya hadits riwayat Umar yang melarang menjual harta wakaf telah sampai kepada Abu Hanifah, tentulah dia akan menarik pendapatnya tersebut dan pasti berpendapat sesuai dengan petunjuk hadits (AshShan'ani, Muhammad Ibn Ismail). Dengan demikian jelas bahwa konsep yang dikemukakan oleh imam Abu Hanifah tersebut dapat dipahami bahwa mewakafkan harta itu sama halnya dengan meminjamkannya.Perbedaannya hanyalah terletak pada keberadaan benda itu sendiri.Kalau harta wakaf berada dalam pengawasan wakif, sedangkan pinjam meminjam bendanya berada pada orang yang memanfaatkan harta tersebut.

Kedua definisi yang dikemukakan oleh imam Syafi'iyah, sebagian murid Abu Hanifah dan Hanabilah, yaitu wakaf adalah menahan harta yang mungkin dimanfaatkan serta kekal materi hartanya (baqa' 'ainih) dengan terputus hak mentasharrufkannya melalui pernyataan wakif atau orang lain untuk tujuan yang mubah, atau mendistribusikan manfaatnya untuk kebaikan dalam rangka mendekatkan diri kepada Allah (Habs mal yumkin al-intifa' bih ma'a baqa' 'ainih bi qath'I at-tasharruf fi raqabatih min al-waqif wa ghairih 'ala mashrif mubahin maujudin au bi shraf rai'ih 'ala jihah birr wa khair taqarruban ila Allah ta'ala).

Dari definisi di atas dapat dipahami sebagai berikut: pertama, harta wakaf itu haruslah merupakan harta yang mempunyai manfaat yang lama, bukan yang cepat rusak atau yang cepat habis. Kedua, harta yang telah diwakfkan itu bukan lagi menjadi milik waqif (orang yang mewakafkan) dan bukan pula milik orang lain, melainkan telah berpindah menjadi milik Allah.Ketiga mewakafkan harta itu adalah untuk selama-lamanya, dan tidak dibenarkan mewakafkan harta untuk waktu tertentu atau terbatas.Keempat, terwujudnya wakaf manakala telah ada pernyataan dari waqif (orang yang berwakaf), terpenuhi rukun-rukun dan syaratsyazratnya.Apabila sudah terpenuhinya rukun dan syarat, maka baru terwujudlah kepastian adanya wakaf. Dengan demikian apabila wakaf dianggap telah sah, maka yang berwakaf tidak dapat menarik kembali wakafnya, dank arena itu puola 
waqif tidak lagi mempunyai hak untuk mentasharrufkannya (mentransaksikannya), yakni menghibahkannya atau menjualkannya, dan seandainya wakif meninggal dunia, maka tidak diwarisi oleh ahli warisnya.

Al-Jurjani mengemukakanbahwa menurut syara' wakaf adalah menahan benda dari kepemilikan dan berdekah dengan manfaatnya (Al-Jurjani, 1988:253). Sedangkan Ibn al-Qasim. merumuskan bahwa wakaf adalah suiatu tindakan menahan harta yang dapat dimanfaatkan tanpa habis seketika dan untuk penggunaan yang ibadah (dibolehkan hokum agama) serta dimaksudkan untuk mendekatkan diri kepada Allah atau mencari keridhaan-Nya (Muhammad Ibn alQasimi).

Ketiga definisi yang refresentatif dalam mazhab Maliki, yaitu wakaf adalah menahan harta dari mentransaksikannya dan menyedekahkan manfaatmanfaatnya untuk tujuan-tujuan kebaikan, sebagai pemberian yang mengikat (tabarru' lazim), serta bendanya tetap menjadi milik wakif, dengan pernyataan untuk waktu yang tertentu dari pihak wakif (yang member wakaf) tidak disyaratkan untuk selamanya (Habsal-'ain 'am ayyi tasharrufin tamlikiyin wa yatarr'u birai'iha lijihah khairiyah tabarru'an laziman bi shighah ma'a baqa' al'ain 'ala milk al-waqif muddatan mu'ayyanatan min az-aman, fala yusytarathu fih at-ta'bid. Dengan demikian, jelas bahwa pertama, sama dengan mazhab Hanafi, bahwa harta yang diwakafkan itu tetap menjadi milik pihak yang berwakaf. Kedua, berbeda dengan mazhab Hanafi bahwa pihak yang berwakaf tidak boleh mentransaksikan harta yang diwakafkan tersebut, dengan kata lain pihak yang berwakaf tidak boleh menariknya kembali, menjualnya, kecuali apabila harta wakaf tidak bermanfaat lagi, tidak boleh mewariskannya atau menghibahkannya. Ketiga dalam mazhab Maliki wakaf itu boleh untuk waktu tertentu, tidak mesti untuk selamanya.

Semenrata itu dalam Kompilasi Hukum Islam Pasal 215 dirumuskan bahwa wakaf adalah perbuatan hukum seseorang atau kelompok orang atau badan hukum yang memisahkan sebagian dari benda miliknya dan melembagakannya untuk selama-lamanya guna kepentingan ibadah atau keperluan umum lainnya sesuai dengan ajaran Islam (Kompilasi Hukum Islam). Sedangkan dalam UndangUndang Nomor 41 Tahun 2004 tentang Wakaf pasal 1ayat 1 dirumuskan bahwa: Wakaf adalah perbuatan hukum wakif untuk memisahkan dan/atau menyerahkan sebagian harta benda miliknya untuk dimanfaatkan selamanya atau untuk jangka waktu tertentu sesuai dengan kepentingannya guna keperluan ibadah dan/atau kesejahteraan umum menurut syariah.

\section{PEMBAHASAN PENELITIAN}

Sedangkan masalah yang tidak kalah pentingnya yang dihadapi adalah pertama, bagaimana cara memberdayakan harta wakaf produktif dan uang secara optimal agar bisa lebih produktif sekaligus memberikan masukan yang cukup signifikan sehingga benar-benar dapat memberikan manfaat untuk kemaslahatan umat. Kedua, bagaimana cara menghilangkan kendala-kendala yang menghalangi pengoptimalan tersebut, Dengan demikian tawaran solutif agar pengelolaan harta wakaf bisa optimal dan memberikan hasil yang sebanyak-banyaknya bagi 
kepentingan mauquf'alaiyh, maka penurut penulis ada lima langkah yang mesti dilakukuan sebagai berikut:

1. Menghilangkan pandangan fikih tertentu yang menjadi penghalang pengoptimalan pemanfaatan harta wakaf. Kendala fikih ini timbul dari pandangan ulama fikih mazhab tertentu yang sangat ketat tentang pengelolaan harta wakaf. Dalam pamdangan penulis, mazhab Syafi'i yang dianut sebagian besar umat Islam di Indonesia merupakan mazhab yang ketat dalam masalah wakaf, jika dibandingkan dengan mazhab-mazhab lainnya.

Wakaf dalam mazhab Syafi'i mempunyai hukum yang ketat, sehingga kadangkadang menyulitkan fihak nazhir dalam mengelolakan harta wakaf tersebut. Berikut ini adalah pandangan mazhab Syafi'i tentang wakaf yang menyulitkan pengelolaan wakaf di antaranya adalah:

a. Harta wakaf tidak boleh dijual, meskipun sudah rusak

b. Harta wakaf tidak boleh ditukar

c. Harta wakaf tidak boleh diberikan pada fihak lain.

Hal inilah yang menunjukkan demikian ketatnya pandangan mazhab tersebut, sehingga dikatakan dalam Fath al-Mu'in yang sangat terkenal dan banyak digunakan dalam pesanteren"

"Barang wakaf tidak boleh dijual, meskipun sudah rusak. Maka jika sebuah masjid sudah runtuh dan sukar untuk direnovasi, ia tetap tidak boleh dijual, karena masih bias dilakukan shalat dan 'itikaf di atas tanah masjid tersebut.

Undang-Undang Wakaf Nomor 41 Tahun 2004, Bab IV Pasal 40 juga memuat dua ketentuan di atas. Namun dalam pasal-pasal berikutnya, seperti Bab IV Pasal 41 dan Bab V Pasal 44 memberikan ruang pada pemerintah, Badan Wakaf Indonesia dan Nahzir wakaf untuk menyikapi hal tersebut secara arif. Meskipun demikian, pandangan mazhab Syafi'I tersebut masih melekat kuat dalam masyarakat. Oleh sebab itu, perlu usaha sosialisasi yang intens agar apa yang terkandung dalam undang-undang wakaf tersebut tidak mendapat reaksi sekaligus penolakan dalam masyarakat. Usaha sosialisasi yang lebih serius sangat diperlukan karena undang-undang ini sudah disahkan enam tahun yang lalu, akan tetapi masyakat masih banyak yang masih buta tentang hal-hal yang baru twersebut. Sebagai contoh masyarakat masih banyak yang tidak tahu tentang boleh wakaf uang dan diproduktifkan begitu juga dengan benda-benda yang lain yang bergerak sebagaimana diatur dalam Bab II Pasal 16, Pasal 28, Pasal 29, Pasal 30 dan Pasal 31.

Kepada masyarakat juga perlu dikenalkan pandangan yang lebih moderat tentang pengelolaan harta wakaf, seperti pandangan dalam mazhab Hanafi yang memperbolehkan menjual harta dengan syarat-syarat tertentu.

2. Menentukan payung hukum yang jelas dan payung hukum yang tegas atas harta wakaf tersebut. Sehingga harta wakaf tidak beralih menjadi harta perseorangan atau keluarga tettentu serta fihak yang menjadi pengelola harta wakaf tidak sewenang-wenang dalam mengolahnya. Dalam hal ini status hukum yang jelas amat diperlukan bagi semua harta termasuk harta wakaf. Tanpa status hukum yang jelas harta wakaf bisa berubah menjadi milik pribadi. Bab II Pasal 30 dan Bab III Pasal 32 agar setiap harta wakaf mesti didaftarkan kepada instansi yang berwenang dan Badan Wakaf Indonesia, merupakan 
aturan yang baik sekali. Namun kekurangan dalam pasal ini menyebutkan sanksi atas yang melanggarnya masih terlalu ringan sedangkan batas waktu pendaftaran harta wakaf. Batas waktu pendaftaran harta wakaf disebutkan, yaitu tujuh hari, akan tetapi sanksi bagi yang melanggarnya hanya bersifat sanksi administrative tanpa denda dan tanpa sanksi hukuman badan (UndangUndang Wakaf Bab IX Pasal 68). Ini adalah sanksi yang ringan dan tidak seimbang dengan kesalahannya. Sebab akibat yang ditimbulkan dari kelalaian tersebut bias berupa hilangnya harta wakaf yang nilainya terkadang mencapai ratusan milyar rupiah.

Dalam pandangan penulis, undang-undang yang sanksinya ringan akan sulit dilaksanakan dan akan banyak terjadi pelanggaran. Oleh karena itu perlu dilakukan penyempurnaan undang-undang ini dengan memberikan sanksi yang lebih berat atas kelalain dalam mendaftarkan harta wakaf. Sehingga undangundang ini dapat menjadi payung hukum yang tegas atas harta wakaf. Dalam hal ini penulis menganggap bahwa Pasal 67 yang memuat sanksi atas penyelewengan dalam mengelolakan harta wakaf masih terlalu ringan. Sebab kejahatan yang disebutkan dalam pasal tersebut sebenarnya adalah kejahatan korupsi. Maka seharusnya hukuman maksimalnya harus bisa lebih dari 5 tahun dan hukuman dendanya harus bias lebih dari 500 juta rupiah sebab harta wakaf yang dikorupsi bisa bernilai ratusan milyar rupiah. Karenanya menurut pandangan penulis, undang-undang yang sanksinya sangat ringan tentu akan sulit dilaksanakan dan kemungkinan akan banyak pelanggaran Dalam hal ini, perlu dilakukan penyempurnaan undang-undang dengan memberikan sanksi hukuman yang lebih berat atas kelalaian dalam mendaftarkan harta wakaf. Sehingga diharapkan undang-undang ini dapat menjadi payung hukum yang tegas atas harta wakaf.

Dalam Pasal 67 yang memuat sanksi atas penyelewengan mengelolakan harta wakaf masih terdapat hokuman yang terlalu ringan. Sebab kejahatan yang disebutkan dalam pasal tersebut yang sebenarnya adalah merupakan kejahatan korupsi. Maka seharusnya hukuman yang ditetapkan hukuman maksimalnya harus bisa lebih berat dari 5 tahun dan hukuman dendanya harus bias lebih dari 500 juta rupiah sebab harta wakaf yang dikorupsikan bisa bernilai ratusan milyar rupiah.

3. Menjadikan harta wakaf produktif harus lebih produktif lagi. Hal ini tentu dapat dilakuakn dengan cara memberdayakan harta wakaf secara baik sesuai dengan kondisinya, letak dan sifatnya. Sebab banyak harta wakaf yang letaknya jauh dari produktif. Sehingga membuat hasilnya sangatlah kurang sekaligus tidak sesuai dengan apa yang diharapkan oleh wakif maupun nazhir wakaf.

Dalam hal ini, kalau mengikuti qaul mazhab Syafi'i tentulah harta tersebut tidak bolehb ditukar menjadi harta lain yang lebih produktif. Dalam undangundang wakaf yang ada (pasal41) juga tidak memberikan ruang yang besar untuk melakukan pertukaran dengan harta lain yang lebih produktif. Satusatunya pengecualian dari ketentuan dalam pasal sebelumnya (pasal 40 tentang larangan pertukaran harta wakaf, penjualan, penghibahan dan lain sebagainya) adalah bagi kepentingan RUTR (Rencana Umum Tata Ruang). Maka hal ini 
tentunya akan menjadikan gerak bagi pengelola wakaf yang akan memproduktifkan harta wakaf akan menjadi terbatas sekali, hal ini juga akan menjadi kendala dalam menjadikan harta wakaf dapat menjadi lebih produktif. Dalam hal ini ada banyak cara untuk menjadikan harta produktif menjadi benar-benar lebih produktif adalah sebagai berikut: a) Jika harta produktif berupa tanah, maka lokasi tanah kadang-kadang tidak dapat menolong pengelolanya untuk lebih memproduktifkannya. Misalnya harta wakaf berupa tanah ratusan hektar akan tanah tersebut terletak di pegunungan atau di tengah hutan belantara. Tentunya hal ini akan lebih menyulitkan bagi pengelolanya jika pengelolanya berpikir secara tradisional dalam mengelolakan harta tersebut dan menanaminya dengan tanaman yang tradisional pula. Akan tetapi jika pengelolanya berpikir lebih kreatif dan berani membuat terobosanterobosan baru, maka tenttunya tidak akan menjadi kesulitan bagi pengelolanya untuk menjadikan harta wakaf itu menjadi lebih produktif, asalkan disertai dengan modal usaha yang cukup. Tentunya pengelola itu akan dapat melalukannya dengan menanam tanaman yang lebih banyak menghasilkan uang daripada tanaman yang tradisional. Salah satu tanah yang luas tadi ditanami dengan membuat kebun kelapa di tanah yang tadinya hutan belantara. Tetapi jika tanah itu terletak di atas pengunungan dapat ditanami dengan kebun kopi dan yang lainnya. Sebaliknya juga jika tanah itu terletak dikota di tepi jalan yang strategis, maka tentunya akan dapat didirikan ruko atau rukan dan kemudian disewakan, atau dengan membangun rumah atau gedung untuk disewakan. Juga jika harta itu berupa tanah tanah yang cukup luas dan terletak di tepi kota, maka akan dapat dijadikan proyek perumahan. b) Jika harta wakaf itu berupa bangunan yang terltak di tempat yang strategis, akan dapat disewakan untuk kantor, took, perumahan dan lainnya. Lain halnya jika tanah tersebut tidak terletak pada tempat yang tidak strategis, maka tentunya ini akan menjadi masalah jika hal ini benar-benar terjadi sebab telah terjadi pemubaziran atau bahkan penyelewengan dari fihak yang mengelolakan wakaf dan yang mebuat banguna tersebut, dalam hal ini perlu mengambil tindakan yang tegas. c) Jika harta wakaf itu berupa uang tunai, maka bisa dijadikan lebih produktif dengan membeli saham perusahaan yang menguntungkan atau membeli property yang mempunyai nilai yang tinggi, baik dari segi pemasukan sewa atau dari segi pertambahan nilai.

Dalam negara yang seluas dan sebesar dan seluas Indonesia denga kegiatan ekonomi yang begitu bervariasi serta puluhan ribu perusahaan yang beroperasi di pelbagai macam bidang, tentu hal ini tidak akan susah dilakukan. Dalam hal ini, tentunya harus memiliki pakar yang berpengalaman dan jujur untuk membantu melakukan penanaman modal tersebut. Salah satu contoh di Negara Malaysia Tabung Haji dikelola mirip dengan harta wakaf tunai. Karenanya para pengelolanya sangat berhati-hati dalam mengelolakan harta tersebut dan mempunyai bidang operasi penanaman modal pada sektor-sektor tertentu saja sebagai berikut:

a. Membuka dan mengusahakan kebun kelapa sawit. Misalnya Tabung Haji memiliki dan mengoperasikan beberapa perkebunan kelapa sawit di Sumatera dan Malaysia Timur. 
b. Membeli dan membangun proyek perumahan dan menyewakannya. Ini dilakukan oleh Tabung Haji di beberapa wilayah yang padat penduduk di Malaysia Barat.

c. Membeli atau membangun kompleks ruko dan menyewakannya . Tabung Haji ini telah melakukan hal tersebut di daerah Ipoh ibukota negeri (propinsi) Perak di Malaysia Barat.

d. Membeli atau membangun bangunan dan mengoperasikannya. Ini dilakukan di Kuala Lumpur (ibukota Malaysia) dan Johor Baru (ibukota Propinsi Johor).

4. Melatih nazhir agar lebih professional dalam tugasnya atau melantik tenaga yang handal dan professional untuk pengelolaan harta wakaf tersebut dengan diberi imbalan yang yang sesuai dengan tugas dan kewajibannya. Kebiasaan yang terjadi di masyarakat adalah orang melantik nazhir dari lingkungan ulama atau tokoh masyarakat. Hal ini terjadi, kaarena pewakaf ingin wakafnya berada di bawah pengawasan orang-orang yang dapat dipercaya sehingga akan dapat terhindarkan dari penyelewengan, yang diketahui selama ini para nazhir yang ditunjuk bukanlah orang-orang yang handal dalam mengelola harta wakaf secara produktif. Kenyataan yang terjadi di masyarakat adalah bahwa para ulama dan pemuka masyarakat yang ditunjuk seringkali merupakan orang yang tidak mempunyai keahlian dalam berbisnis dan mengelola harta wakaf secara produktif, berbeda dengan halnya jika harta wakaf yang bukan produktif, sebuah masjid atau mushalla, hal ini tentu sudah benar dan tidak menimbulkan masalah.

Akan tetapi masalah bisa timbul jika harta wakaf adalah harta yang produktif yang seharusnya dikelola oleh orang-orang yang paham tentang bagaimana menjadikan harta tersebut menjadi benar-benar produktif serta mempunyai nilai keuntungan yang tinggi, agar dapat member manfaat yang lebih banyak kepada mauquf 'alayh. Karenanya harus ada kejelasan perbedaan antara tugas sebagai nazhir dan tugas sebagai pengelola harta wakaf produktif. Sebab seorang nazhir lebih berfungsi sebagai pengawas atas harta wakaf produktif agar tidak diselewengkan, sedangkan seorang pengelola harta wakaf haruslah seorang profesional yang bertugas membisniskan harta wakaf agar dapat memberikan keuntungan yang setinggi-tingginya. Dengan demikian, seorang nazhir tersebut haruslah dididik dan dilatih agar dapat mengelolakan harta wakaf dengan baik, sebab jika harta wakaf itu banyak maka tentu saja akan tetap ada masalah yang timbul disebabkan karena kerja nazhir adalah kerja sambilan dan bukan kerja selamanya. Jadi solusinya adalah haruslah dibedakan posisi nazhir yang kerjanya sepanjang masa bagi harta wakaf dengan seorang nazhir yang kerjanya hanya sambilan saja. Juga harus dibedakan antara harta produktif yang bisa dikelola oleh satu orang nazhir yang bukan professional dengan dalam pengelolaan harta wakaf produktif dengan seorang nazhir yang memang professional dalam mengelola harta wakaf produktif. Untuk meningkatkan pengelolaan harta wakaf produktif hal-hal yang perlu diperhatikan adalah:

a. Untuk pengelolaan harta produktif yang bernilai tidak banyak dan bias diurus oleh satu orang, maka jika nazhirnya sepanjang masa dan bukan 
sambilan, maka nazhir tersebut harus mendapat latihan yang cukup bagi pengelolaan harta tersebut. Hal ini bias dilakukan melalui pelatihanpelatihan dan kursus-kursus jangka pendek. Pelatihan ini juga merupakan kewajiban badan wakaf Indonesia bersama dengan Kementerian Agama. Namun jika nazhir tersebut tetap tidak mampu melaksanakan tugasntya dengan baik, maka ia harus segera dilengserkan dan diganti dengan nazhir yang lain yang memang mampu melaksanakan tugasnya. Dan penggantian nazhir tersebut harus segera dilakukan serta tidak boleh ditunda-tunda, karena akan menimbulkan kemudharatan yang besar terhadap harta wakaf tersebut.

b. Sebaliknya jika nazhir tersebut tidak sepenuh masa tetapi hanya merupakan kerja sambilan saja, maka nazhir hanya berperan sebagai pengawas saja. Dan pengelolaan harta wakaf harus diserahkan kepada seorang yang bekerja sepenuh masa dan mempunyai keahlian yang cukup (profesional). Pelatihan yang perlu diberikan kepada nazhir seperti ini adalah untuk memberikan pengetahuan kepadanya dan nazhir tersebut juga tahu cara mengawasi kerja orang dengan baik dan efektif.

c. Jika harta wakaf produktif tersebut banyak dan tidak bisa dikelola secara langsung oleh seorang nazhir saja, maka tugas nazhir mengelolakan harta wakaf diserahkan kepada satu badan yang profesional dalam mengurus harta wakaf produktif. Maka dalam hal ini tugas nazhir hanyalah sebagai pengawas saja sedangkan hartanya dikelolakan oleh orang-orang atau badan yang profesional dan digaji oleh pengurus wakaf. Sedangkan untuk nazhir yang hanya bertugas mengawasi harta wakaf, maka pelatihan yang diperlukan adalah hanya sebatas tugasnya sebagai pengawas saja. Namun jika ia mengetahui hal-hal yang berkenaan dengan pengelolaan harta sejenis, juga hal ini akan lebih baik baginya. Dengan demikian Badan Wakaf Indonesia dan Kementerian Agama harus menyelenggarakan dua jenis pelatihan kepada nazhir agar harta wakaf dapat dikelola lebih efektif dan produktif. Yakni pelatihan untuk nazhir yang bertugas untuk mengawasi dan pelatihan untuk nazhir yang bertugas mengelolakan sendiri harta wakaf tersebut. Jadi untuk lebih memperoduktifkan harta wakaf yang produktif, maka harta wakaf itu harus harus dikelola oleh orang yang profesional dan mumpuni dalam pengurusan harta wakaf tersebut agar dapat lebih produktif, hal ini sesuai dengan peringatan Rasulullah saw. Dalam hadits yang artinya: Jika urusan diserahkan kepada yang bukan ahlinya, maka tunggulah kehancurannya.

Dalam hadits ini jelas merupakan kaidah yang universal yang berlaku di manamana, termasuk dalam pengurusan harta wakaf produktif. Dengan kata lain, jika seorang nazhir memang professional dalam mengelola harta wakaf produktif serta ia juga mempunyai tenaga dan waktu yang cukup, maka lebih baik biarlah dia sendiri yang mengurusi harta wakaf tersebut. Maka jika ia menyelwengkan tugasnyanya atau tidak mampu memikulnya, hal ini tentu dapat digantikan kepada orang lain yang lebih mampu untuk mengurusi harta tersebut atau harta tersebut dapat dikelola oleh lembaga atau badan yang memang bisa mengelolanya dengan baik sedangkan nazhir bertugas hanya 
sebagai pengawas dari harta wakaf .Sedangkan tugas Badan Wakaf Indonesia dan Departemen Agama adalah memberikan pelatihan yang sebaik-baiknya kepada nazhir sesuai dengan tugas yang diembannya. Hal-hal yang harus diperhatikan oleh nazhir adalah sebagai berikut:

a. Transparency. Seorang nazhir harus memanage harta wakaf secara tranparan dan secara rutin membuat laporan keuangannya yang bisa dilihat atau diakses oleh wakif.

b. Productivity. Seorang nazhir haruslah mampu memanage dana wakaf secara produktif sehingga orang-orang yang berhak menerima wakaf bisa memanfaatkan dana tersebut secara berkesinambungan.

c. Trustable (bisa dipercaya). Integritas seorang nazhir sangatlah penting. Sebab sifa inilah yang akan menjauhkannya dari tindakan penyelewengan.

5. Membuat program yang terencana baik bagi pemberdayaan semua harta wakaf tersebut dan melakasanakannya dengan baik. Sebab banyak manfaat yang bisa dicapai dengan memberdayakan harta wakaf yang produktif, baik dalam bidang ekonomi, sosial dan agama. Dalam bidang agama yang memang sudah diketahui bahwa agama Islam memang menyuruh agar menjadikan harta wakaf bermanfaat dengan sebaik-baiknya. Makin luas manfaat seseorang maka tentunya akan akan makin baik dalam pandangan agama Islam begitu juga halnya dengan harta, makin bermanfaat maka akan makin bagus. Hal ini sejalan dengan sabda Rasulullah saw. yang artinya sebaik-baik manusia adalah yang paling bermanfaat kepada manusia.

Disamping itu juga haruslah ada orang yang memiliki wawasan yang jauh ke depan tentang harta wakaf yang produktif serta mempunyai kemampuan manajerial yang bagus untuk mengelolakan harta wakaf yang ada dalam skala yang besar. Manajer tersebut juga harus didukung oleh satu perangkat staf yang bisa bekerjasama dengan baik. Dengan dukungan Badan Wakaf Indonesia (BWI), maka jika hal ini bisa diwujudkan akan tercapailah impian untuk menjadikan harta wakaf sebagai kekuatan ekonomi yang diperhitungkan dalam kegiatan ekonomi nasional sekaligus juga dapat mensejahterakan seluruh umat Islam di Indonesia. Hal ini semua masih merupakan mimpi yang belum terwujud, dikarenakan menyangkut pendataan wakaf yang masih belum selesai juga. Indonesia dalam hal ini, masih perlu banyak belajar kepada negara Kuwait yang telah sukses dalam memberdayakan harta wakaf. Dan tentunya harus ada kerja yang lebih keras dalam pengelolaan harta wakaf yang masih belum tertata dengan baik. Untuk mewujudkan mimpi ini haruslah mempunyai program yang lebih terencana dalam memajukan pengelolaan harta wakaf agar bisa lebih produktif dan lebih bermanfaat bagi umat Islam serta bagi bangsa Indonesia. Dengan demikian jelas bahwa secara umum ada empat hal yang bisa dikaji lebih lanjut untuk mewujudkan sebuah kultur berwakaf yang sehat di Indonesia. Empat hal tersebut adalah: manajemen fundraising (pencarian wakif), manajemen pengelolaan wakaf, manajemen penyaluran wakaf, dan edukasi masyarakat mengenai wakaf.

Ada tujuh prinsip yang mungkin bisa diterapkan dalam pengelolaan wakaf di Indonesia.Tujuh prinsip itu antara lain: 
1. Prinsip Objektif.

Dalam prinsip ini sebelum aset dialokasikan atau diinvestasikan, dewan pengawas/pertimbangan perlu membuat kebijakan yang akan member signifikansi kontribusi terhadap pencapaian tujuan. Kebijakan tersebut meliputi:

a. Peran dana wakaf dalam mendukung misi institusi.

b. Peran dana wakaf dalam menjaga neraca keseimbangan keuangan.

c. Berapa jumlah dana yang harus kembali dan berapa jumlah dana yang harus diinvestasikan ulang.

d. Berapa jumlah pemberian dana yang bisa diambilkan dari dana wakaf.

e. Biaya operasional yang bisa diambilkan dari dana wakaf.

f. Strategi investasi secara menyeluruh, alokasi aset secara khusus.

g. Siapa yang seharusnya bertanggung jawabterhadap keputusan investasi.

h. Keputusan investasi mana, jika ada, yang seharusnya didelegasikan kepada konsultan, advi-sor atau manajer investasi dari luar institusi.

2. Prinsip Kebijakan Pengeluaran Uang.

Dalam memutuskan jumlah dana dari sumbangan ke dalam anggaran operasional per-tahun, dewan pengawas bekerja sama dengan pengelola administrasi, harus cermat terhadap keseimbangan antara dua pihak: kebutuhan institusi dan penerima dana versus kewajiban untuk mempertahankan dana bagi masa depan lembaga. Kompleksitas permasalahan lembaga non profit seperti nazhir wakaf memang tidak hanya berkutat pada masalah berapa perolehan dana dari wakif dan berapa uang yang dibutuhkan untuk menjalankan operasionalisasi lembaga, namun juga ketepatan penggunaan dana. Sebab terkadang dana hanya terkonsentrasi pada beberapa program popular yang hanya member sedikit pengaruh terhadap pencapaian tujuan. Dan kesalahan dalam membuat perkiraan pengeluaran uang, akan menyebabkan neraca keuangan timpang dan berakhir kepada kebangkrutan lembaga.

3. Prinsip Alokasi Aset.

Uang yang diperoleh dari wakaf hakikatnya adalah dana investasi yang bisa langsung dibagi ke semua pos yang terkait. Namun banyak pula wakaf yang tidak langsung uang, seperti tanah atau benda berharga lainnya. Jika wakaf tidak berbentuk uang, maka nazhir perlu menerapkan manajemen investasi yang kertat agar harta wakaf tersebut tidak menguap karena salah investasi. Semua aset wakaf harus diklasifikasikan berdasarkan nilai, keawetan, resiko dan biaya pengelolaannya. Dan pilihan kepada produk deposito dan produk sekuritas memang mudah dan bisa diprediksi pendapatannya, namun situasi ekonomi di Indonesia yang mudah dilanda krisis, hal ini, mengharuskan nazhir lebih cermat melihat kondisi sosial politik seacara makro. Oleh karena itu nazhir wakaf harus memilih manajer yang tepat.

4. Prinsip Seleksi Manajer.

Dengan adanya klasifikasi aset, maka akan diperoleh pula diversifikasi manajer untuk masing-masing klasifikasi.Maka untuk memilih majaer bagi setiap jenis asetdiperlukan kemampuan khusus, karena manajer yang akan dipilih tidak hanya memiliki kemampuan manajerial saja tapi juga harus mempunyai pemahaman keagamaan dan berakhlaq baik. Maka diperlukan wawancara yang 
mendalam dengan harapan bisa mengeksplorasi sejarah hidup si calon manajer karena jika hanya mengandalkan data tertulis mengenai si calon manajer, dikhawatirkan ada yang tidak terlihat atau mungkin saja sengaja disembunyikan oleh kandidat. Meskipun masa lalu kandidat tersebut tidak menjadi tolok ukur mengenai performa kerja di masa depan, namun hal itu perlu diketahui agar pilihan manajer bisa benar-benar tepat. Seleksi manajer bisa pula dioutsourcing-kan ke lembaga manajemen atau perguruan tinggi untuk meringankan tugas nazhir. Dalam proses seleksi manajer tidak selesai saat sudah terpilih manajer saja, namun ada proses selanjutnya yakni proses monitoring secara regular yang akan melihat kinerja dan perubahan yang terjadi terhadap perkembangan aset.

5. Prinsip Manajemen Resiko.

Dalam manajemen wakaf akan ada resiko yakni hilangnya aset dan kegagalan memperoleh nilai lebih/keuntungan dari ekstraksi aset. Akibat yang paling ringan adalah tidak adanya anggaran operasional, sementara akibat terbesar adalah hingnya aset wakaf. Sebagaimana diketahui bahwa saat aset diklasifikasi dan pengelolaanya menjadi tanggungjawab masing-masing manajer maka akan terjadi subyektifitas terhadap model pengelolaannya. Begitu juga dengan pemetaan target hasil bisa menjadi boomerang jika hasil yang dicapai jauh dari harapan. Dalam hal ini, tentu akan sangat riskan untuk menginvestasikan harta wakaf dalam investasi yang fluktuatif meskipun terkadang cepat memberi keuntungan. Tentu akan lebih baik jika investasi dilakukan ke dalam pilihan yang lebih aman meskipun keuntungannya berjalan lambat.

6. Prinsip Biaya.

Dalam prinsip ini muncul pertanyaan wajib " Dapatkah kita memperoleh hasil yang sama dengan modal yang sedikit?" Sebab seringkali biaya investasi terasa terlalu tinggi karena tidak adanya koordinasi dalam mensinkronisasi subsidi aset dari klasifikasi aset lain atau terjadi karena membengkaknya biaya operasional. Karenanya diperlukan pengontrolan biaya. Dalam hal ini, control biaya memuat tiga hal penting yakni 1) Ketelitian dalam penempatan manajer. 2) Negosiasi gaji/honor.3) Efisiensi manajemen pengelolaan investasi. Sebab biaya manajemen bisa juga berarti menghindari transaksi yang tidak perlu. Namun pengurangan reduksi biaya juga akan membutuhkan biaya. Yang perlu diperhatikan jangan mengambil resiko penghematan namun berakhir pada kesalahan biaya. Keseimbangan neraca keuangan adalah merupakan kuncinya.

7. Prinsip Tanggung Jawab.

Agar terciptanya iklim kerja yang efektif, dinamis dan harmonis dalam program investasi wakaf, maka wajib didefinisikan peran dewan pengawas, nazhir, staff, manajer investasi, dan konsultan. Semuanya harus tertulis dengan jelas dan disepakati serta dipahami bersama agar tidak terjadi tumpang tindih pekerjaan maupun saling menyalahkan dan tanggung jawab masing-masing pada pelaksanaan program. Sebagaimana dimaklumi bahwa tugas seorang nazhir wakaf adalah ibadah dan gaji yang diterima adalah upah dalam beribadah. Karenanya tidak ada seorang nazhir wakaf yang boleh mempermainkan tanggungjawab dari Allah untuk mengelola harta wakaf dan 
dengan ini juga ia akan memperoleh penghasilan. Dengan kata lain, bahwa sebagai sebuah tim, maka nazhir wakaf harus mampu mengelola pribadipribadi yang terlibat di dalamnya. Kinerja tim yang optimal dapat dicapat dengan kesetiaan kepada komitmen, baik kelembagaan maupun personal serta konsistensi terhadap pencapaian tujuan. Komitmen yang didukung oleh tanggungjawab dan skill yang mumpuni ini akan mengarahkan kepada optimalisasi kerja.

Dengan kata lain, tentunya sangat tepat sekali jika lembaga pengelola wakaf menggunakan edukasi masyarakat untuk mendukung program-programnya karena wakaf ditujukan untuk hasil jangka panjang. Dengan mendorong kesadaran masyarakat melalui program-program wakaf dan membentuk opini melalui media massa, tentunya wakaf akan menjadui kultur baru, trend baru dan gaya hidup baru bagi semua lapisan masyarakat. Tumbuhnya kebiasaan baru dalam berwakaf, disatu sisi merupakan peluang bagi lembaga pengelola wakaf, tapi di sisi lain juga tantangan karena dituntut profesionalisme dalam pengelolaannya.

Wacana pemberdayaan ekonomi umat melalui sertifikasi wakaf dengan uang tunai yang lazim dikenal Sertifikat Wakaf Tunai (Cash Wakaf Certificate) kini sudah mulai dirasakan manfaatnya, meskipun pengaplikasiaanya masih dilakukan oleh beberapa lembaga filantrofis sendiri, karena sistem wakaf ini yidak terlepas dari pendekatan yang digunakan baik aspek konseptual, sistematika maupun metodologinya.

Wakaf tunai (Cash Wakaf/waqf al-nuqud) adalah wakaf yang diberikan oleh Muwakif/Wakif (orang yang berwakaf) dalam bentuk uang tunai yang diberikan kepada lembaga pengelola wakaf (Nazhir) untuk kemudian dikembangkan hasilnya untuk kemaslahatan umat. Sementara itu pokok wakaf tunainya tidak boleh habis sampai kapanpun.

Kebolehan wakaf tunai sudah diatur dalam UU No 41 tahun 2004 yang belum lama ini disahkan oleh DPR RI serta berdasarkan fatwa MUI Indonesia taggal 11 Mei 2002 yang berbunyi:

1. Wakaf uang (cash wakaf/waqf al-nuqud)adalah wakaf yang dilakukan seseorang, kelompok orang, lembaga atau badan hukum dalam bentuk uang tunai.

2. Termasuk ke dalam pengertian uang adalah surat-surat berharga.

3. Wakaf uang hukumnya jawaz (boleh)

4. Wakaf uang hanya boleh disalurkan dan digunakan untuk hal-hal yang dibolehkan secara syar'i. Nilai pokok wakaf uang harus dijamin kelestariaannya, tidak boleh dijual, dihibahkan atau diwariskan.

Hadirnya konsepsi wakaf uang/tunai adalah merupakan manifestasi dari ajaran Islam yang terlkait dengan akumulasi dana yang dialokasikan untuk kesejahteraan umat/masyarakat. Hal ini sejalan dengan sabda Rasulullah yang diriwayatkan Imam Bukhari: "Apabila Bani Adam meninggal dunia, maka terputuslah amalnya kecuali tiga perkara: Amal jariah, Anal sholeh yang selalu mendoakan kedua orang tuanya dan ilmu yang dimanfaatkannya." Para ulama sepakat bahwa yang disebut amal jariyah salah satunya adalah wakaf. Akumulasi 
dana melalui wakaf ternyata memiliki potensi yang sangat luar biasa, baik secara kualitas maupun kuantitasnya.

Sistem pengelolaan wakaf uang tidak banyak berbeda dengan wakaf tanah atau bangunan, dalam hal ini, nazhir bertugas untuk menginvestasikan sesuai syariah dengan satu syarat: nilai nominal uang yang diinvestasikan tidak boleh berkurang. Sedangkan hasil investasi dialokasikan untuk upah nazhir (maksimal $10 \%$ ) dan untuk kesejahteraan masyarakat (minimal 90\%). Wakaf uang sebagai suatu gerakan baru dalam dunia perwakafan terutama di Indonesia mampu mengambil peranan yang signifikan dalam merancang program-program perberdayaan masyarakat. Dalam hal ini, tugas pemberdayaan dalam masyarakat tentunya bukanlah tugas dari pemerintah semata, namun setiap elemen masyarakat harus turut serta dalam memberdayakan masyarakat. Tentunya program pemberdayaan masyarakat dalam dilakukan dengan sitem perwakafan, hal ini, sesuai denag Undang-undang No. 41 tahun 2004 tentang wakaf yang telah mengamanatkan Badan Wakaf Indonesia agar mengelola harta benda wakaf yang berskala nasional dan internasional. Sebagaimana diketahui bahwa sifat utama perwakafan yang mengharuskan kekal dan abadi pokok hartanya, lalu dikelola dan hasilnya disalurkan sesuai dengan peruntukannya dan juga harus sesuai dan selaras dengan program sistem jaminan sosial atau asuransi.. Dalam perwakafan juga, pihak wakif dapat menentukan peruntukan hasil pengelolaan harta wakaf (mauquf'alaih).

Dalam ketentuan undang-undang terdapat dua model wakaf uang, yaitu wakaf uang untuk jangka waktu tertentu dan wakaf uang untuk selamanya. Untuk wakaf uang untuk waktu tertentu haruslah diinvestasikan ke produk perbankan agar lebih aman dan memudahkan pifah wakaf dalam menerima uangnya kembali pada saat jatuh tempo. Sedangkan untuk wakaf uang untuk selamanya, dalam hal ini pihak nazhir memilki otoritas penuh untuk mengelola dan mengembangkan uang wakaf untuk mencapai tujuan wakafnya. Jika kegiatan investasi menggunakan dana penghimpunan wakaf, maka atas keuntungan bersih usaha hasil investasi ini (yaitu pendapatan kotor dikurangi dengan biaya operasional), maka akan dibagikan sesuai dengan ketentuan undang-undang wakaf yaitu $90 \%$ keuntungan akan diperuntukkan untuk tujuan wakaf (mauquf 'alaih) dan $10 \%$ untuk penerimaan pengelola atau nazhir.

Sebagaimana diketahui bahwa wakaf uang dapat dipergunakan dalam berbagai bentuk sistem jaminan sosial, seperti asuransi tenaga kerja, asuransi pension dan asuransi jiwa. Serta dapat juga untuk mengatasi berbagai macam masalah seperti perumahan,akses permodalan dan pendidikam bagi si miskin yang dapat dilakukan melalui memaksimalkan pengelolaan dan pendayagunaan zakat. Dengan pendayagunaan wakaf uang ini sebagai suatu sistem jaminan social maka diharapkan program pemberdayaan masyarakat dapat saling terintegratif dengan program pemberdayaan yang dilaksanakan oleh pemerintah. Mekanisme efek pengganda wakaf uang dapat dijelaskan sebagai berikut, yaitu dana wakaf uang yang dikelola oleh nazhir untuk diinvestasikan akan memberikan hasil, dimana hasil 10\% diberikan kepada nazhir sebagai biaya pengelolaan dan 90\% hasilnya diberikan untuk mauquf 'alaih. Hasil alokasi yang diinvestasikan untuk mauquf 'alaih dalam hal ini dapat dibedakan atas duasektor yaitu sektor ekonomi dan 
sektor non ekonomi seperti untuk sosial dan pendidikan. Hasil wakaf uang yang diberikan untuk sektor ekonomi yaitu dalam bentuk dana bergulir. Bantuan tambahan modal yang diberikan dapat digunakan untuk meningkatkan kapasitas produksi, sehingga produksibarang dan jasa dalam perekonomian akan meningkat. Peningkatan penerimanaan negara akan meningkatkandaya pembangunan, peningkatan dana pembangunan ini akan kembali lagi secara tidak langsung kepada peningkatan pendapatan wakif.

Dengan demikian jelas bahwa besarnya manfaat wakaf uang bagi pemberdayaan masyarakat, perlu didorong suatu kesadaran masyarakat agar mampu berperan serta aktif dalam gerakan wakaf uang ini.Potensi dana yang cukup besar dari wakaf uang akan mampu memberikan kemaslahatan yang lebih besar bagi pembangunan umat dan kesejahteraan masyarakat. Dan juga wakaf uang yang dikelola dapat juga memberikan efek pengganda dalam perekonomian, baik hasil investasi waklaf uang tersebut diberikan dalam bentuk bantuan sektor ekonomi maupun sektor non ekonomi. Hasil ini secara langsung dan tidak langsung akan mampu memberikan pengaruh signifikan dalam mengentaskan kemiskinan

Keberadaan bank-bank syariah dipandang sebagai lembaga alternatif yang cukup representatif dalam mengelola dana amanah tersebut. Dan untuk lebih memahami kemungkinan-kemungkinan yang dapat dimainkan perbankan syariah dalam mengelola wakaf tunai, hal ini diperlukan untuk mengetahui ketentuanketentuan perbankan dalam kegiatan usaha bank yang terkait dengan masalah wakaf, antara : SK Dir. BI No.32/34/KEP/DIR tanggal 19 Mei 1999, tentang bank umum berdasarkan prinsip syariah, pasal 29 ayat 2 yang berbunyi, " Bank dapat bertindak sebagi lembaga baitul maal yitu menerima dana yang berasal dari zakat,infaq,shadaqah, wakaf, hibah, atau dana sosial lainnya dan menyalurkannya kepada yang berhak dalam bentuk santunan dan/atau pinjaman kebajikan (qardhul hasan). Dari ketentuan di atas, dapat dilihat bahwa secara umum bank syariah dapat mengambil peran sebagai penerima dan penyalur dana wakaf, sedangkan peran bank syariah sebagai pengelola dana wakaf tidak disebutkan secara eksplisit. Wewenang pengelolaan ini dipandang penting karena statusnya berbeda dengan dana sosial lainnya, seperti zakat, infaq, dan shadaqah.

Tujuan Bank syariah mengelola dana wakaf sebagaimana diamanahkan oleh Undang-undang No 41 tahun 2004 Tentang Wakaf antara lain: Karena bank, dapat menyediakan jasa layanan perbankan dengan menerbitkan sertifikat wakaf tunai dan melakukan manajemen investasi terhadap dana wakaf tersebut. Membantu melakukan mobilisasi tabungan sosial dan melakukan transformasi dari tabungan social ke modal. Juga memberikan benefit kepada masyarakat khususnta, masyarakat miskin melalui optimalisasi sumberdaya masyarakat kaya. Menumbuhkan kesadaran kepada masyarakat kaya tentang tanggung jawab sosialnya dan membantu perkembangan pasar modal sosial ( social capital market). Dan untuk seorang wakif, tentunya mereka yang mempunyai kelebihan likuiditas tersebut. Saat ini umunya kelebihan likuiditas masyarakat disimpan di bank. Dalam hal ini, potensi calon wakif tersebut dapat dilihat oleh bank dengan mengamati jumlah deposito, tabungan atau mutasi giro yang bersangkutan, 
sehingga akses ke calon wakif lebih mudah dilakukan oleh bank beserta dengan jaringannya.

Sedangkan perbankan syariah memang memiliki kemampuan untuk melakukan investasi dana wakaf dengan berbagai jenis investasi, seperti investasi jangka pendek, jangka menengah dan jangka panjang. Serta mampu pula mendistribusikan hasil investasi dana wakaf tersebut, hal ini, tentunya dengan mengacu pada persyaratan yang diberikan oleh wakif terhadap pihak yang berhak menerima benefit. Misalnya, benefit yang diizinkan oleh wakif dapat dipergunakan sebagai dana bergulir untuk pemberdayaan ekonomi lemah. Oleh karenanya perbankan syariah dianggap layak sebagai nazhir wakaf uang. Selain memberikan porsi cukup pada perbankan syariah dalam mengelola wakaf uang melalui jalan investasi, lembaga-lembaga swasta lain yang memiliki kredibilitas baik dalam pengelolaan investasi yang sesuai dengan konsep syariah haruslah juga diberi kesempatan untuk mengelola wakaf uang. Hal ini juga pernah dilakukan oleh Nazhir Wakaf Dompet Dhuafa dengan Batas Capita.

Wakaf tunai ini mudah dikelola dan dikembangkan menjadi wakaf produktif karena memiliki banyak alternatif penempatan investasi, baik di portofolio keuangan domestik ataupun global. "Penempatan lainnya adalah portofolio keuangan mikro, maupun portofolio investasi di sektor riil." Wakaf uang juga hanya boleh disalurkan dan digunakan untuk hal-hal yang dibolehkan oleh syar'i. Sementara itu nilai pokok wakaf uang harus dijamin kelestariannya, tidak boleh dijual, dihibahkan, atau diwariskan. Di sisi lain juga sesungguhnya perbankan syariah di Indonesia khususnya, memiliki akses yang baik pada lembaga pengelola wakaf skala internasional seperti APIF. Awqaf Properties Invesment Fund (APIF) sebagai salah satu lembaga wakaf dunia yang didirikan oleh IDB tahun 2001 yang bertujuan membiayai aset-aset wakaf yang layak secara sosial, ekonomi dan finansial, di negara anggota dan komunitas muslim di negara non anggota. Dalam hal pengelolaan wakaf, perlu ada standar pengelolaan yang dibakukan agar dana yang dikumpulkan dapat diberdayakan secara maksimal. Sesungguhnya banyak motivasi, kemauan dan kemampuan lembaga keuangan syariah, dalam hal ini perbankan syariah yang secara kelembagaan dan manajemen keorganisasian siap melaksanakan pengelolaan wakaf uang sebagai salah satu aspek pendanaan atau funding dalam mekanisme perbankannya. Ini ditunjukkan dengan keahlian mereka dalam memobilisasi dana yang diterima dari DPK. Sementara itu wakaf uang, menurut laporan keuangannya masuk kedalam Dana Pihak Ketiga, meski saat ini perbankan syariah baru memposisikan diri mereka sebagai penerima wakaf uang saja, belum menjadi nazhir atau pengelola dan penyalur maupun menjadi fund manajer dana wakaf uang yang ada.

Dalam hal ini, peran perbankan atau Lembaga Keuangan Syariah sangat diperlukan. LKS dapat berperan sebagai nazhir yang mengumpulkan, menyalurkan dan mengelola dana wakaf. Maka untuk mendukung keberhasilan pengembangan aspek produktif dari dana wakaf tunai, perlu diarahkan model pengelolaan dana tersebut kepada sektor usaha yang produktif dengan lembaga usaha yang memiliki reputasi yang baik. Seperti menjamin kerjasama (networking) dengan perusahaan model ventura. Kerja sama ini juga dimaksudkan untuk mengaplikasikan model pembiayaan mudharabah maupun musyarakah. 
Untuk lebih memahamkan kepada masyarakat tentang konsep wakaf tunai, manfaat utama adalah sebagai berikut: pertama, wakaf tunai jumlahnya bisa bervariasi sehingga seseorang yang memiliki dana yang terbatas bisa mulai memberikan dana wakafnya tanpa harus menunggu menjadi tuan tanah terlebih dahulu. Kedua, melalui wakaf tunai, aset-aset wakaf yang berupa tanah-tanah kosong bisa mulai dimanfaatkan dengan pembangunan gedung atau diolah untuk lahan pertanian. Ketiga, dana wakaf tunai juga bisa membantu sebagian lembagalembaga pendidikan Islam yang cash flow-nya terkadang kembang kempis serta dengan memberikan gaji civitas akademika dengan ala ladarnya. Keempat, umat Islam dapat lebih mandiri dalam mengembangkan dunia pendidikan tanpa harus tergantung pada anggaran pendidikan negara yang memang semakin lama semakin terbatas.

Dengan demikian, jelaslah bahwa melihat potensi wakaf uang ini, maka tak heran jika lembaga keuangan syariah seperti perbankan syariah akan mampu mengelola bahkan mengembangkan potensi tersebut dengan segala atribut yang perbankan sandang.Dan dengan wakaf uang akan bisa menjadi andalan untuk pengembangan ekonomi umat, bisa dikelola dan dikembangkan untuk peningkatan kesejahteraan dan kemajuan bangsa. Yang tak kalah pentingnya wakaf uang pun bisa bersinergi dengan infaq, zakat dan shadaqah.

\section{KESIMPULAN}

Di Indonesia, secara riil kendala yang dihadapi adalah: pertama, wakaf dipahami hanya berbentuk barang yang tidak bergerak, seperti tanah dan bangunan. Kedua, kendala dalam pelaksanaan wakaf tunai, khususnya dalam hal sosialisasi kepada masyarakat. Ini dikarenakan belum adanya undang-undang wakaf yang spesifik sebagaimana dengan undang-undang zakat. Ketiga, belum optimalnya lembaga-lembaga pengelola wakaf (nazhir) dalam mengelola wakaf yang semestinya keberadaannya menjadi faktor penentu dalam pemanfaatan harta wakaf dan digunakan dalam bentuk produktif, misalnya upaya peningkatan kegiatan usaha kecil, dan lain sebagainya. Dan kendala yang lebih menentukan lagi adalah belum adanya regulasi yang jelas dimana wakaf menjadi sumber pendanaan yang tiada habis-habisnya bagi pengembangan ekonomi umat.

Munculnya bank-bank syari'ah, khususnya yang dimotori oleh bank-bank besar konvensional di hampir seluruh pelosok tanah air memberikan angin besardan optimisme tinggi bagi umat Islam, termasuk di dalamnya pengelolaan harta (dana) wakaf secara produktif. Untuk harta wakaf yang berbentuk harta tidak bergerak seperti tanah dan bangunan, pihak bank syari'ah bisa menjadikannya sebagai agunan (jaminan) peminjaman sejumlah data dalam rangka pengembangan harta wakaf yang lain. Sedangkan kalau dalam bentuk tunai (cashwakaf) uang, maka pihak bank bisa langsung mengelola, mengembangkan dan menyalurkan harta wakaf yang dipercayakan kepada bank tersebut.

\section{DAFTAR PUSTAKA}

Ali Muhammad., Guru Dalam Proses Belajar Mengajar,(Bandung: Sinar baru Algensindo, 1996) 
I-Finance Vol. 4. No. 1. Juni 2018 Listiawati

Ali Mohammad Daud, Sistem Ekonomi Islam Zakat dan Wakaf,( Jakarta: UIPress, 1988)

Abul Abas bin Suraij, Al-Muhadzab, jilid 1, Nihayah Al-Muhtaj, jilid 4. AlKhashah,

Al-Bahr Al-Ra'iq, jilid 5. Al-Is'af, dan Ahkam-Al-Auqaf.

Darmiyati Zuchdi, Strategi Meningkatkan Kemampuan Membaca,( Jakarta: Rineka Cipta, 2010)

Damsar, Pengantar Sosiologi Ekonomi,( Jakarta: Kencana, 2011)

Fatwa MUI tanggal 11 Mei tahun 2002 MUI Tentang Wakaf Uang AlGhamarawi, Siraj al- Wahhaj, (Beirut: Dar Al-Fikr: tt al-Hashmi,Sherafat 'Management of Waqf: Past and Present" dalam Management and

Development of Awqaf, Proceeding of the Seminar,(Jeddah: Islamic Research and Training Institute, Islamic Developmen Bank, 1987)

Harahap Sumuran, Wakaf Uang Dan Prospek Ekonominya Di Indonesia, SolusiEfektif

Pemberantasan Kemiskinan Dan Penganggurran,( Jakarta: Mitra Abadi Press, 2012)

Hafidhudin Didin,Agar Harta Berkah dan Bertambah: Gerakan Membudayakan Zakat,

Infak,sedekah dan Wakaf, (Jakarta:Gema Insani Press, 2007)

Halim Abdul,Hukum Perwakafan di Indonesia, (Tangerang : Ciputat Press, 2005)

Ibrahim Duski, Wakaf dalam Perspektif Fikih dan Perundang Undangan, (Palembang: Grafika Telindo Press 2008)

Iskandar, Metodologi Penelitian Kualitatif, (Jakarta: GP Press, 2009).

Idrak M., Dkk (Tim Peduli Pelajar), Sosiologi Untuk SMA X, XI, XII, (Yogyakarta:

Messemedia 2010)

Al-Jurjani.At-Ta'rifat,( Beirut: Dar al-Fikr:1988) Jawad Mughniyah, Muhammad, al-Ahwal as-Syakhsiyyah, (Beirut: Dar Ilmi al-Malayin, t.t),

Al-Kabisi Muhammad Abid Abdullah, Ahkam al-Waqf fi Al-Syariah Al-Islamiyah, terj, Ahrul Sani, (Jakarta: Cahaya Persada IIMan),

----------Hukum Wakaf, (Jakarta: Dompet Dhuafa Republika, 2004)

Kurniawan Aries, Bank Syariah Sebagai Pengelola Dana Wakaf, Yayasan Lembaga Konsumen Indonesia. Diakses di www,ylki.or.id

Lubis K Suhrawardi, Wakaf dan Pemberdayaan Umat, (Jakarta: Sinar Grafika, 2010).

Mughinah Mohammad Jawad, Fiqh Lima Mazhab, Penerjemah Masyukur A.B, dkk (Jakarta: Lentera, 1996)

Mubarok Jaih, Hukum Perwakafan (Jakarta: Sinar Grafindo :2008\}

Mannan, M.A, Sertifikat Wakaf Tunai; Sebuah Inovasi Instrumen Keuangan Islam, (Jakarta: Ciber, PkttI-UI, terj, 2001)Muhammad Ibnu Mukarram alAnshari Ibnu Mansur Jamal al-Din , Lisan al 'Arab (t.p, Dar al-Ma'arif, $\mathrm{t}$, th), jilid 6

Muhammad Bakar Ibnu Ahmad Ibnu AbiSahal as-Syarakhi al-Hanafi,Kitab Mabsuth, (Beirut al-Kutub al-Ilmiyah, 2001), juz 11 
I-Finance Vol. 4. No. 1. Juni 2018 Listiawati

Mujiono dan Dimiyati, Belajar dan Pembelajaran, (Jakarta: PT Rineka Cipta, 1999).

Ngadiyono, Kepemimpinan dan Organisasi Sosial,„Jakarta: Raja Grafindo, 2006

Nasution, Mustafa E dan Uswatun Hasanah (ed), Wakaf Tunai Inovasi Finansial Islam.

Jakarta: PSTTI- UI. 2006

Sula, M. Syakir. Implementasi Wakaf dalam Instrumen Asuransi Syariah. Jurnal Al- Awqaf,

Vol II, No.2, Jakarta: BWI, April, 2009

Qudamah,Ibnu,Raudhah An-Nazhir wa Junnah al-Munazhir, ( ar-Riyadh: alKulliyah asy-Syari'ah. 1987), Juz 2

- Al-Kafi, jilid 2. DanSyarh Ghabah Al-Muntaha, jilid 4.

Al-Qayyim,Ibnu,I'lam al-Muwaqi'in 'an rabb al-'alamin, (Beirut: Dar alFikr.1977).

Al-Qasimi Muhammad, Ibnu,Rawa'i al-Bayan, (Beirut: Dar al-Fikrl 2: tt)

Qahaf Mundzir,Managemen Wakaf Produktif, (Jakarta: Khalifa, 2005)

Qal'ah Ji Muhammad Rawas, Mausu'ah Fikh Umar Ibn al-Khattab. (Beirut:Dar an-Nafais, $1409 \mathrm{H}$ )

----------Mabahis fi al-Iqtishad al-Islami min Ushulih al-Fiqhiyah. (Beirut: Dar an-Nafais 2000).

Pusat Bahasa Departemen Pendidikan Nasional, Kamus Besar Bahasa Indonesia (KBBI),

Pusat Bahasa Departemen Pendidikan Nasional: Jakarta, 2008)

Pudji M,ulyono dan Djaali, Pengukuran dalam Bidang Pendidikan, (Jakarta:Grasindo, 2007)

Rochaety, Metode Penelitian Bisnis,( Jakarta: Mitra Wacana Media, 2009.).

Rosalinda, Manajemen Wakaf Produktif, (Jakarta: RajaGrafindo Persada 2015)

Rasyid Sulaiman, Fiqh Sunnah. (Bandung: Sinar Baru Algensindo, 2014)

Sujarweni Wiratna, Metodologi Penelitian, (Yogyakarta: Pustaka Baru Press, 2014).

Sujiono Anas,Pengantar Statistik Pendidikan, (Jakarata : Rajawali Pers, 2009)

-------Pengantar Evaluasi Pendidikan, (Jakarta: Raja Grafindo Persada, 2007).

Sudaryono, Dasar-dasar Evaluasi Pembelajaran, (Yogyakarta:Penerbit Graha Ilmu, 2012)

Soulaeman M. Munandar, Ilmu sosial dasar (Teori dan Konsep ilmu social), (Bandung, PT Refika Aditama, 2001)

Ash-Shan'ani, Muhammad Ibn Ismail.tt.Subul As-Salam, Mesir:Muhammad Ali Shabih

Sayyid Abi Bakar Syaththa, I'anah ath-Thalibin, juz 4, Mesir:Musthafa alHalabi.tt

Sujiono Anas, Pengantar Evaluasi Pendidikan, Jakarta: Raja Grafindo Persada, 2007.

Sudjana Nana, Evaluasi Proses dan Hasil Pembelajaran,( Jakarta: Bumi Aksara, 2010) 